\title{
Satellite-tracking of female loggerhead turtles highlights fidelity behavior in northeastern Brazil
}

\author{
Maria Ângela Marcovaldi ${ }^{1, *}$, Gustave G. Lopez ${ }^{1}$, Luciano S. Soares ${ }^{1}$, \\ Eduardo H. S. M. Lima ${ }^{1}$, João C. A. Thomé ${ }^{2}$, Antonio P. Almeida ${ }^{2}$ \\ ${ }^{1}$ Fundação Pró-TAMAR, Caixa Postal 2219, 41950-970 Salvador, BA, Brazil \\ ${ }^{2}$ Projeto TAMAR/ICMBio, Cx Postal 105, 29900-970 Linhares, ES, Brazil
}

\begin{abstract}
We studied inter- and postnesting movements in the major loggerhead Caretta caretta nesting population in Brazil. Ten breeding females were satellite-tracked from nesting grounds in the state of Bahia, northeastern Brazil, for up to $1284 \mathrm{~d}$. Eight females stayed in the nesting area after deployment, showing fidelity between internesting home ranges and nesting locations, even at a local scale. During postnesting movements, all of the turtles migrated to the northern coast of Brazil to individual foraging areas on the continental shelf. Distances between nesting and foraging areas reached up to $2400 \mathrm{~km}$, and migration lasted from 28 to $47 \mathrm{~d}$. Five females were tracked during subsequent breeding migrations to the nesting area at different remigration intervals of 2 or $3 \mathrm{yr}$. Females were also tracked during a second postnesting migration back to foraging areas, and these showed strong fidelity to foraging grounds. Movements to and from foraging grounds occurred along the shelf, clearly delineating a migratory corridor. The northern coast of Brazil, specifically the coast of the state of Ceará, is an important foraging ground for loggerheads nesting along the northern coast of Bahia.
\end{abstract}

KEY WORDS: Satellite-tracking $\cdot$ Caretta caretta $\cdot$ Internesting $\cdot$ Postnesting $\cdot$ Migration $\cdot$ Brazil

\section{INTRODUCTION}

Loggerhead Caretta caretta migrations from nesting to feeding areas are known from early tag-recapture studies (Bustard \& Limpus 1971, Meylan 1982). More recently, satellite telemetry and the integrated use of GPS have revealed new possibilities of studying important aspects of habitat use by sea turtles (Godley et al. 2008).

The first satellite telemetry studies focused on postnesting loggerheads (Stoneburner 1982, Timko \& Kolz 1982). Since then, the increase in the use of this tool has been continuous, with the development of new equipment and deployment procedures (Godley et al. 2008). Several behavioral aspects have been revealed, for different populations and in diverse developmental stages (e.g. Polovina et al. 2004).

Information on internesting movements can be derived from tag-recapture studies (Tucker et al. 1996, Limpus \& Limpus 2001), direct observation (Limpus \&
Reed 1985), sonic and radio telemetry (Hopkins \& Murphy 1981, Hopkins-Murphy et al. 2003) and satellite telemetry (Stoneburner 1982, Godley et al. 2003a,b, Zbinden et al. 2007, Tucker 2009, 2010). Long-term tag-recapture (Limpus \& Limpus 2003) and satellite telemetry studies (Hawkes et al. 2007, Girard et al. 2009) have delineated foraging areas. Loggerhead fidelity to foraging grounds is inferred from early tag-recapture studies (Hughes 1982, Limpus et al. 1992); however, the main limitations of this methodology include tag loss and biases in the likelihood of recapture and reporting. Although flipper tags enable the tracking of individuals over long periods, no information is available regarding the intervening route and habitat preferences (Godley et al. 2008). In contrast, satellite telemetry studies provide significant information regarding each study individual, yet few telemetry studies are available to corroborate previous findings. 
The northern coast of the state of Bahia comprises the main loggerhead nesting area in Brazil (Marcovaldi \& Marcovaldi 1999, Marcovaldi \& Chaloupka 2007). Over $28 \mathrm{yr}$ of tag-recapture data have delineated the reproductive biology and provided important information on inter- and postnesting movements (Marcovaldi \& Laurent 1996, Marcovaldi et al. 2000). However, habitat use during internesting, the location of foraging areas and the migratory behavior between nesting and foraging grounds remain unknown. Delimitation of high-use areas is extremely important to understand important aspects of loggerheads' foraging ecology and to mitigate potential anthropogenic impacts (Zbinden et al. 2007, Hays 2008). The present study aimed to evaluate inter- and postnesting movements on the major loggerhead nesting colony in Brazil.

\section{MATERIALS AND METHODS}

The nesting ground on the northern coast of the state of Bahia, northeastern Brazil (around $13^{\circ} \mathrm{S}$, Fig. 1), comprises the main loggerhead nesting site in Latin America (Marcovaldi \& Chaloupka 2007). The Brazilian National Sea Turtle Conservation and Research Program-Projeto TAMAR/ICMBio maintains 4 field stations in Bahia that protect a $215 \mathrm{~km}$ coast, divided into $1 \mathrm{~km}$ sectors (Fig. 1). See Marcovaldi \& Laurent (1996) and Marcovaldi \& Marcovaldi (1999) for details on the study area.

Ten loggerhead females were equipped with satellite transmitters (KiwiSat 101, Sirtrack) from January 25 to March 5, 2006, during the second half of the nesting season. Transmitters were attached using a 2-part epoxy resin (Tubolit MEP-301) and covered with a layer of antifouling paint. The units were powered by 2 D-size lithium batteries ( $0.5 \mathrm{~W}$ output), and were duty cycled to work $24 \mathrm{~h}$ on, during the first $30 \mathrm{~d}$, and $24 \mathrm{~h}$ on/48 h off thereafter. Transmissions were processed via ARGOS location system (http://argosinc. com) for location information, surface temperature at the time of transmission, battery voltage and number and duration of transmissions.

Five satellite transmitters were deployed on Busca Vida and Jauá beaches (Kilometers 21 to 27), and 5 on Praia do Forte and Imbassaí beaches (Kilometers 69 to 77) (Fig. 1, Table 1).

Each turtle was measured with flexible plastic tape over the curve carapace length (CCL) and tagged with inconel tags on each front flipper (National Band and Tag Co.). Other data, such as date, time, location and tissue samples, were collected according to TAMAR's standardized protocols (Marcovaldi \& Marcovaldi 1999).

Location data provided by ARGOS were analyzed using the Satellite Tracking and Analysis Tool (STAT; Coyne \& Godley 2005) program from seaturtle.org. The most accurate positions (Location Classes [LC] 3, 2, 1 and $A_{\text {; }}$ see Hays et al. 2001) were used to reconstruct routes and calculate distances. LC Z, B and 0 and speeds $>5 \mathrm{~km} \mathrm{~h}^{-1}$ were excluded from analysis.

Geographic information systems software (ArcGis 9.1, ESRI) was used to map turtle movements and calculate high-use areas and movement pathways.

Postnesting migrations were considered completed when movement was no longer directed for at least 3

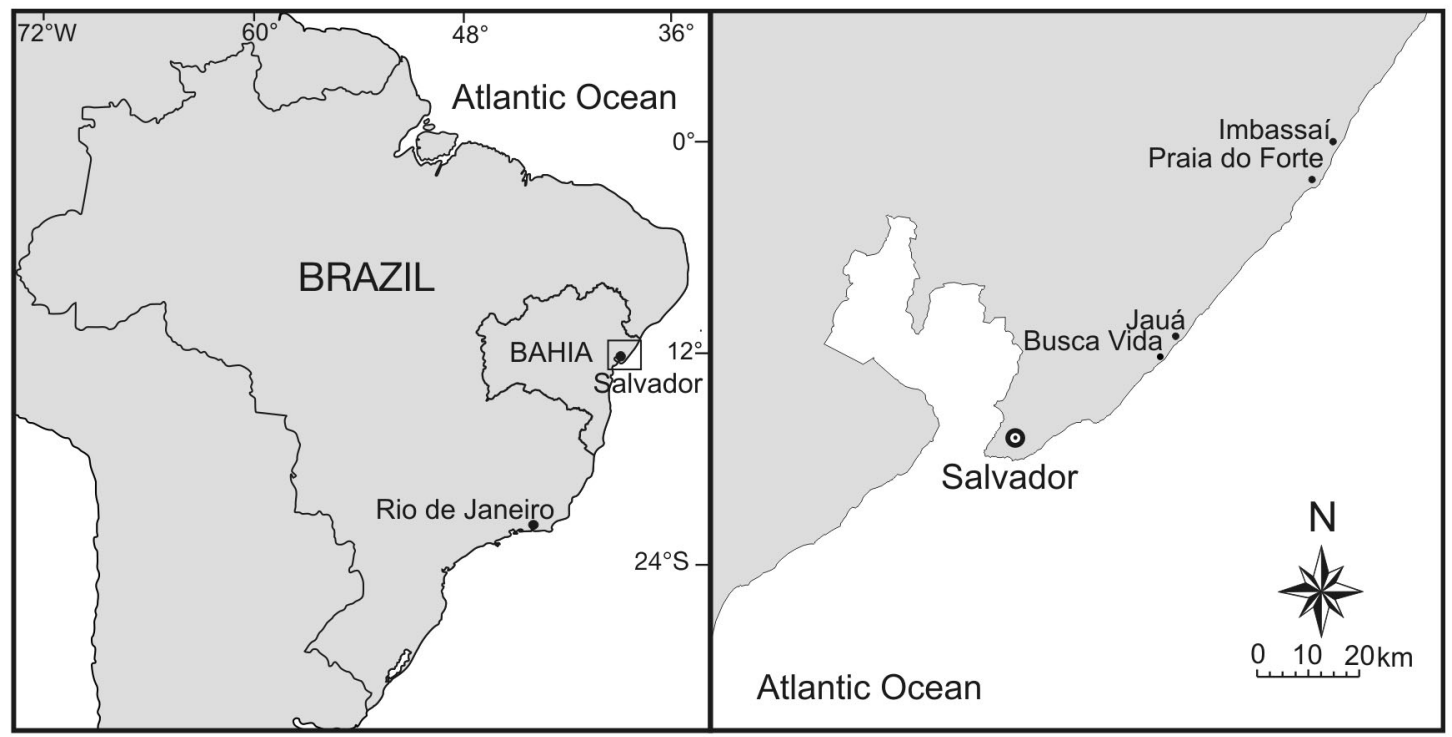

Fig. 1. Caretta caretta. Location of the nesting area in northeastern Brazil 
Table 1. Caretta caretta. Deployment information, tracking period and minimum distance traveled for each tracked loggerhead. CCL: curved carapace length

\begin{tabular}{|lccccc|}
\hline Turtle & $\begin{array}{c}\text { Length } \\
(\mathrm{CCL} ; \mathrm{cm})\end{array}$ & $\begin{array}{c}\text { Deployment } \\
\text { location }\end{array}$ & $\begin{array}{c}\text { Deployment } \\
\text { date in 2006 } \\
(\mathrm{dd} / \mathrm{mm})\end{array}$ & $\begin{array}{c}\text { Days } \\
\text { tracked }\end{array}$ & $\begin{array}{c}\text { Min. distance } \\
\text { traveled (km) }\end{array}$ \\
\hline L1 & 107 & Busca Vida & $25 / 01$ & 593 & 7129 \\
L2 & 99 & Busca Vida & $27 / 01$ & 897 & 6902 \\
L3 & 102 & Praia do Forte & $31 / 01$ & 1284 & 13911 \\
L4 & 100 & Praia do Forte & $03 / 02$ & 1250 & 17681 \\
L5 & 101.5 & Jauá & $14 / 02$ & 426 & 5132 \\
L6 & 100 & Busca Vida & $15 / 02$ & 565 & 5442 \\
L7 & 103 & Imbassaí & $18 / 02$ & 1109 & 12430 \\
L8 & 101 & Praia do Forte & $21 / 02$ & 1249 & 7539 \\
L9 & 101.5 & Busca Vida & $21 / 02$ & 504 & 7127 \\
L10 & 101 & Praia do Forte & $05 / 03$ & 826 & 8680 \\
\hline
\end{tabular}

consecutive days (Zbinden et al. 2008). Foraging areas were identified as those areas where turtles showed restricted movements (multidirectional and backtracked over previous tracks) following postnesting migrations, which continued until the transmitters stopped sending information or until turtles engaged new return migrations (Troeng et al. 2005). To define important habitats for each turtle, we calculated fixed kernel home ranges using Hawth's analysis tools for ArcGIS (Beyer 2004). Using kernel home-range estimates (KHRE) 50\% utilization distributions (UD), we delineated individual and joined core habitatuse areas; $h$ factor was 0.05, calculated following Silverman (1986).

\section{RESULTS}

\section{Internesting movements}

Turtles were tracked for 426 to $1284 \mathrm{~d}$ (mean: $870 \mathrm{~d}$; Table 1). Location data showed that 2 turtles left the nesting beaches immediately after deployment, while 8 stayed for 12 to 66 d (mean: 33.6 d) and displayed subsequent internesting behavior prior to departure. Maximum distance between successive nesting events of a single female varied from 1 to $41 \mathrm{~km}$ (mean: $8.8 \mathrm{~km}$; Table 2).

Excluding the 2 turtles that departed immediately, emergences inferred from Argos location data suggest that 1 female nested 5 times, 2 nested 4 times, 2 nested 3 times and 3 nested twice, including nesting on the deployment date (Table 2).

Maximum perpendicular distance from the coastline during internesting movements varied from 12.1 to $26.4 \mathrm{~km}$ (mean: $19.6 \mathrm{~km}$ ); individual-at-sea areas ranged from 36 to $1392 \mathrm{~km}^{2}$ (mean: $559 \mathrm{~km}^{2}$ ) (Table 2). Turtles mostly remained over the continental shelf, with $72 \%$ of location signals received in waters $<50 \mathrm{~m}$ deep (Fig. 2).

KHREs of 50 and $25 \%$ UD for all turtles showed 2 separated internesting areas ( $<50 \mathrm{~km}$ apart), located in waters adjacent to the 2 main nesting aggregations, Busca Vida and Praia do Forte (Fig. 3). During the internesting period, turtles concentrated their movements in waters adjacent to the main nesting beaches where they were originally tagged, except for a single female that moved among the 2 areas.

Five females were tracked from foraging areas for a subsequent season after 2 (L7, L8, L10) and 3 (L3, L4) nesting years. Return migrations from foraging grounds began in October or early November, lasting from 27 to $66 \mathrm{~d}$ (Table 3).

Turtles returned to the breeding ground where they were originally tagged (i.e. Praia do Forte). Kernelestimated home ranges partially overlapped in all cases (Fig. 4). Turtle L4 moved among the 2 areas (i.e. Praia do Forte and Busca Vida beaches) in both nesting seasons and showed fragmented kernel-estimated use of internesting habitat (Fig. 4). Turtle L10 departed from the nesting beach right after tag deployment, so no information is available for comparison of internesting movements during the first season.

Remigrant turtles remained in the nesting grounds for between 83 and 105 d (Table 3), while the same 4 turtles tracked during the first nesting season stayed in the area from 12 to $44 \mathrm{~d}$ after deployment.

\section{Postnesting movements}

Females migrated for a mean of $27 \mathrm{~d}$ (range: 0 to $66 \mathrm{~d})$ to foraging grounds located on the northern coast of Brazil. Eight females remained on the coast of the state of Ceará, one in the state of Maranhão and one was situated in the state of Pará (Fig. 5). Movements between nesting and foraging grounds occurred along the coast, mainly in waters between 25 and $50 \mathrm{~m}$ depth (Figs. 2 \& 5), with sporadic and short excursions to deeper waters. Three females started migrations by moving into deeper waters for 5 to $7 \mathrm{~d}$, but returned to the shelf later. The minimum travel distances between nesting and foraging areas varied from 1309 to $2439 \mathrm{~km}$ (mean: $1695 \mathrm{~km}$ ), and the mean migration period was $37 \mathrm{~d}$ (range: 28 to $47 \mathrm{~d}$ ), at a mean travel rate of $45.8 \mathrm{~km} \mathrm{~d}^{-1}$ (or $1.9 \mathrm{~km} \mathrm{~h}^{-1}$ ).

Postnesting migrations of the 5 remigrant turtles lasted from 30 to $39 \mathrm{~d}$. All of the females returned to the same foraging ground off the coast of Ceará. 
Table 2. Caretta caretta. Nesting activity information recorded for the loggerheads tagged at the nesting site in the state of Bahia. Maximum interval: maximum distance and time period between first and last records. -: no data

\begin{tabular}{|c|c|c|c|c|c|c|c|}
\hline Turtle & $\begin{array}{l}\text { Record date } \\
\text { in } 2006 \\
(\mathrm{dd} / \mathrm{mm})\end{array}$ & $\begin{array}{c}\text { Record } \\
\text { location } \\
\text { (coastal km) }\end{array}$ & $\begin{array}{l}\text { Distance from } \\
\text { previous } \\
\text { landing }(\mathrm{km})\end{array}$ & $\begin{array}{l}\text { Time interval } \\
\text { between consecutive } \\
\text { records }(\mathrm{d})\end{array}$ & $\begin{array}{l}\text { Maximum } \\
\text { interval } \\
(\mathrm{km} ; \mathrm{d})\end{array}$ & $\begin{array}{l}\text { Internesting } \\
\text { area }\left(\mathrm{km}^{2}\right)\end{array}$ & $\begin{array}{l}\text { Maximum } \\
\text { distance from } \\
\text { coast }(\mathrm{km})\end{array}$ \\
\hline L1 & $\begin{array}{l}25 / 01 \\
08 / 02\end{array}$ & $\begin{array}{l}24 \\
23\end{array}$ & $\begin{array}{l}- \\
1\end{array}$ & $\begin{array}{c}- \\
15\end{array}$ & $(1 ; 15)$ & 36 & 12.1 \\
\hline L2 & $27 / 01$ & 21 & - & - & - & - & - \\
\hline L3 & $\begin{array}{l}31 / 01 \\
14 / 02\end{array}$ & $\begin{array}{l}71 \\
77\end{array}$ & $\overline{6}$ & $\begin{array}{c}- \\
14\end{array}$ & $(6 ; 14)$ & 386 & 17.2 \\
\hline L4 & $\begin{array}{l}03 / 02 \\
17 / 02 \\
03 / 03 \\
18 / 03\end{array}$ & $\begin{array}{l}71 \\
72 \\
31 \\
70\end{array}$ & $\begin{array}{c}- \\
1 \\
41 \\
39\end{array}$ & $\begin{array}{l}- \\
14 \\
14 \\
15\end{array}$ & $(39 ; 43)$ & 1392 & 21.7 \\
\hline L5 & $\begin{array}{l}14 / 02 \\
02 / 03 \\
20 / 03 \\
21 / 04\end{array}$ & $\begin{array}{l}27 \\
22 \\
21 \\
28\end{array}$ & $\begin{array}{l}- \\
5 \\
1 \\
7\end{array}$ & $\begin{array}{l}- \\
16 \\
18 \\
32\end{array}$ & $(7 ; 66)$ & 609 & 21.6 \\
\hline L6 & $\begin{array}{l}15 / 02 \\
01 / 03 \\
15 / 03\end{array}$ & $\begin{array}{l}21 \\
24 \\
33\end{array}$ & $\begin{array}{l}- \\
3 \\
9\end{array}$ & $\begin{array}{l}- \\
14 \\
14\end{array}$ & $(13 ; 28)$ & 718 & 18.1 \\
\hline L7 & $\begin{array}{l}18 / 02 \\
02 / 03 \\
17 / 03\end{array}$ & $\begin{array}{l}77 \\
71 \\
72\end{array}$ & $\begin{array}{l}- \\
6 \\
1\end{array}$ & $\begin{array}{l}- \\
12 \\
15\end{array}$ & $(5 ; 27)$ & 632 & 16.2 \\
\hline L8 & $\begin{array}{l}21 / 02 \\
05 / 03\end{array}$ & $\begin{array}{l}69 \\
68\end{array}$ & $\begin{array}{l}- \\
1\end{array}$ & $\frac{-}{12}$ & $(1 ; 12)$ & 306 & 26.4 \\
\hline L9 & $\begin{array}{l}22 / 02 \\
10 / 03 \\
27 / 03 \\
10 / 04 \\
26 / 04\end{array}$ & $\begin{array}{l}24 \\
21 \\
12 \\
27 \\
31\end{array}$ & $\begin{array}{c}- \\
3 \\
9 \\
15 \\
4\end{array}$ & $\begin{array}{l}- \\
16 \\
17 \\
14 \\
16\end{array}$ & $(19 ; 63)$ & 390 & 23.5 \\
\hline L10 & $05 / 03$ & 69 & - & - & - & - & - \\
\hline
\end{tabular}

\section{Foraging area movements}

All 10 females were tracked to a foraging ground. Five ceased transmissions before leaving these forag-

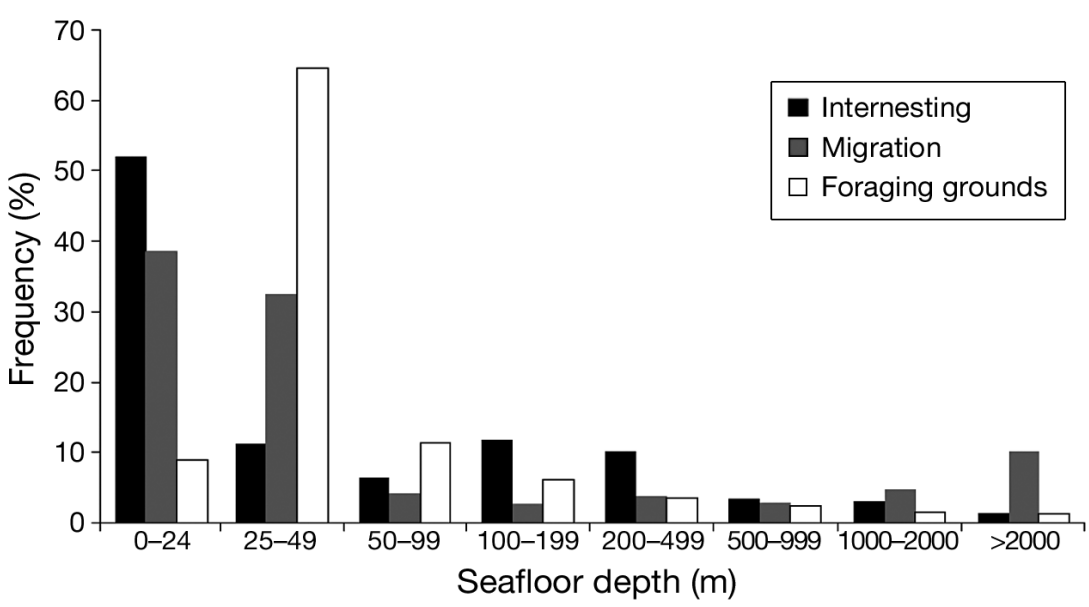

Fig. 2. Caretta caretta. Proportion of locations $(n=3654)$ in relation to bathymetry of the 10 loggerheads tracked from Bahia, during the different phases of the migratory cycle ing areas after periods lasting from 313 to $860 \mathrm{~d}$ (mean: $524 \mathrm{~d}$ ). The 5 remaining turtles left the foraging area for a second nesting season after intervals ranging from 534 to $932 \mathrm{~d}$ (mean: $700 \mathrm{~d}$ ).

KHRE $50 \%$ UD ranged from 545 to $1501 \mathrm{~km}^{2}$ (mean: $889 \mathrm{~km}^{2}$; Table 3) and showed that all individual core foraging areas were usually located in waters between 25 and $50 \mathrm{~m}$ deep (Figs. 2 \& 6). Sea bed substrate was medium-coarse sand and gravel (Dias et al. 2004).

Turtles that returned to foraging areas after a second nesting season showed core foraging areas that overlapped with previous ones, with the exception of turtle L10, which limited its movements to $<15 \mathrm{~km}$ north of the previous areas (Fig. 6). There was no significant relationship between remigration interval and body size. 


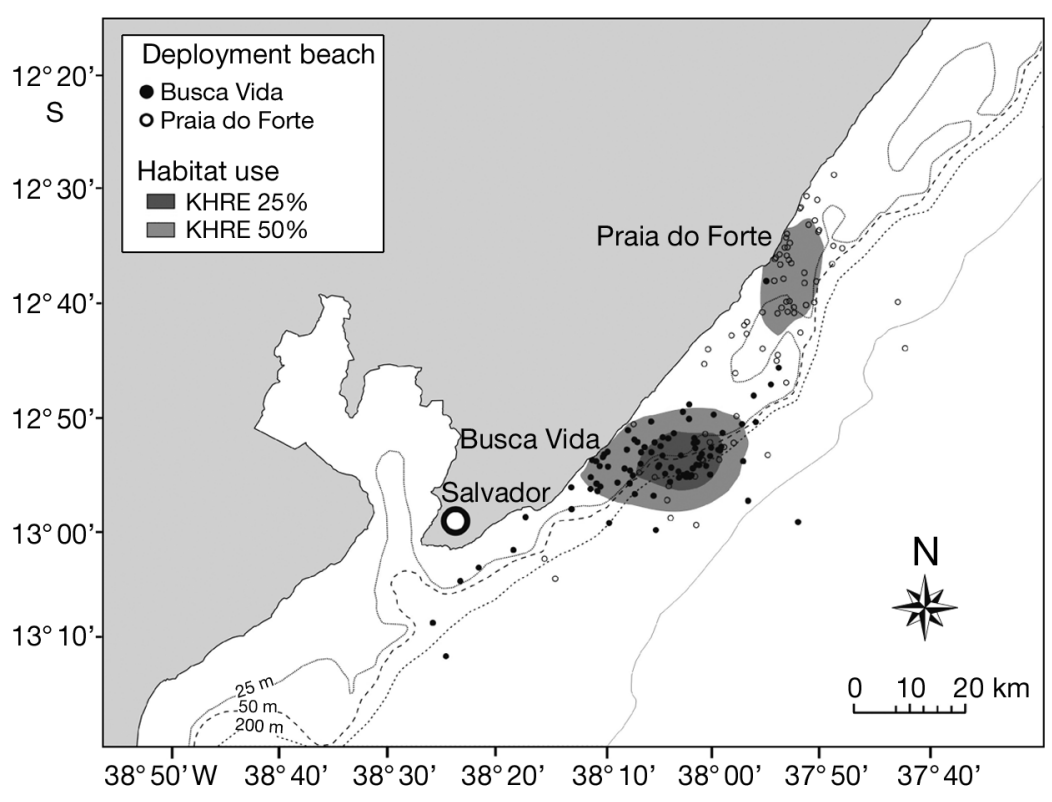

Fig. 3. Caretta caretta. Internesting movements and kernel-estimated homerange utilization distributions (KHRE) of 8 loggerheads satellite-tracked from nesting grounds in Bahia, Brazil

\section{DISCUSSION}

Tracking durations are among the longest reported for satellite-tracked loggerhead studies to date (see Table 4). This indeed allowed us to reveal individual foraging areas and track several turtles through an entire remigration interval for the first time.

Loggerhead females typically remain within the vicinity of the nesting beach during the internesting period (Stoneburner 1982, Sakamoto et al. 1990, Hays et al. 2001, Godley et al. 2003a, 2008), with alongshore instead of offshore movements (Tucker et al. 1996, Hopkins-Murphy et al. 2003). Turtles tracked in the present study showed similar movements; furthermore, except for 1 single female (L4), which moved between the 2 tagging sites, turtles from different beaches did not exchange sites, as evidenced by kernel distribution analysis, remaining very close to the deployment area. Interestingly, turtles that returned for a second nesting season, 2 or 3 yr after the first, occupied similar-sized home range areas which partially overlapped with those of the first season.

Unfortunately, little information is available in the literature quantifying the size of internesting habitats (Table 4). Stoneburner (1982) reported that tracked females entered estuarine waters behind nesting areas following nesting and left these areas after 1 to $3 \mathrm{~d}$, but did not provide information on the entire size of the area used.

Turtles tracked for consecutive breeding seasons (L3, L4, L7 and L8) showed a strong fidelity to nesting grounds, considering the overall scale of migrations from and to foraging areas. However, some factors must be taken into account for comparisons of internesting habitat use in successive breeding seasons. First of all, the transmission duty cycle was different in the 2 tracked nesting seasons; thus, fewer locations were available in the second one. Furthermore, for 2 turtles (L3 and L8), the large intervals between satellite locations prevented the determination of arrival date at the nesting sites.

Migrations to foraging areas start immediately after the last clutch has been laid (Stoneburner 1982, Tucker et al. 1996, Griffin 2002, Plotkin \& Spotila 2002), and are typically nearshore (Papi et al. 1997, Luschi et al. 2006, Hawkes et al. 2007), even if a shorter deep-sea pathway is available (Blumenthal et al. 2006). There are, however, reports of adult loggerheads foraging in oceanic environments (e.g. Hatase et al. 2002, Hawkes et al. 2006). Papi et al. (1997) reported that 1 of 4 tracked loggerheads stopped at a resting area during postnesting migration along the western Indian coast, before heading to the foraging area. Lemke et al. (2003) also reported that 1 turtle tracked settled on a sea mount offshore in the southwestern Atlantic. With the exception of one of the females that made a short excursion off the shelf, all the turtles tracked in our study migrated nearshore, directly towards their foraging areas.

Foraging grounds are generally located 100s (Godley et al. 2003a) or 1000s (Limpus et al. 1992, Papi et al. 1997) of kilometers away from nesting beaches. Limpus et al. (1992) reported mean migration distances of 564 to $1028 \mathrm{~km}$, based on tag-recapture data. Limpus \& Limpus (2001) reported migrations of $>1600 \mathrm{~km}$ between nesting and foraging grounds. Our results fit this long-distance pattern (range: 1309 to $2439 \mathrm{~km}$ ). Our study also documented swimming speeds similar to those noted in previous studies of loggerheads migrating to neritic foraging areas (Zbinden et al. 2008).

In the northwestern Atlantic, turtles from the same nesting population showed different migration patterns, which could be related to different settlement locations after the oceanic developmental period (Hawkes et al. 2007).

Two subpopulations of Brazilian loggerheads exist throughout the region, the southern stock nesting at Rio de Janeiro and Espirito Santo and the northern stock nesting at Bahia and Sergipe (Reis et al. 2009). While the southern stock turtles dispersed both north 

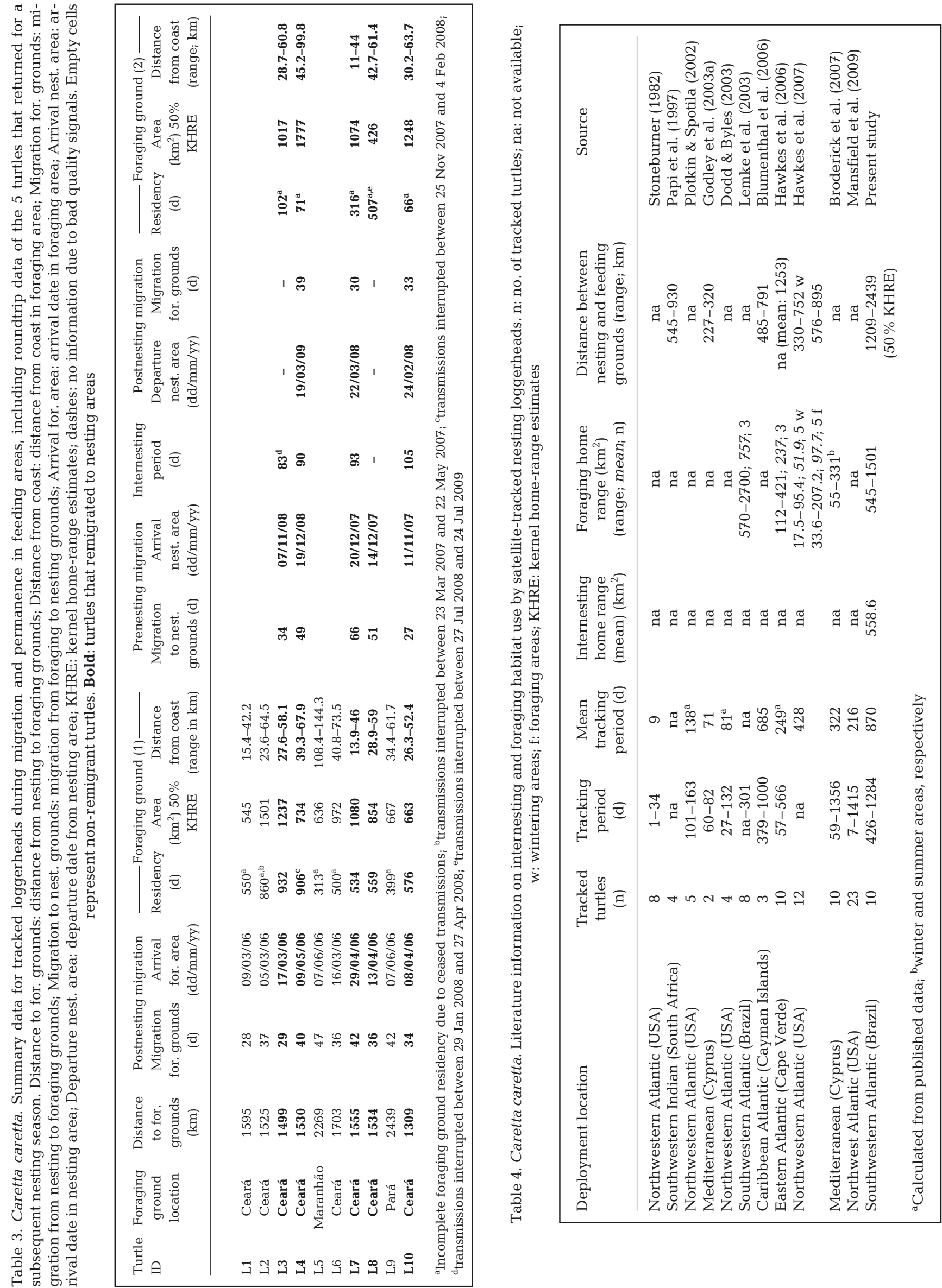




Fig. 4. Caretta caretta. Kernel-estimated home-range utilization 50\% distributions of 4 tracked loggerheads (L3, >L4, L7, L8) showing their first (red) and second (blue) internesting areas

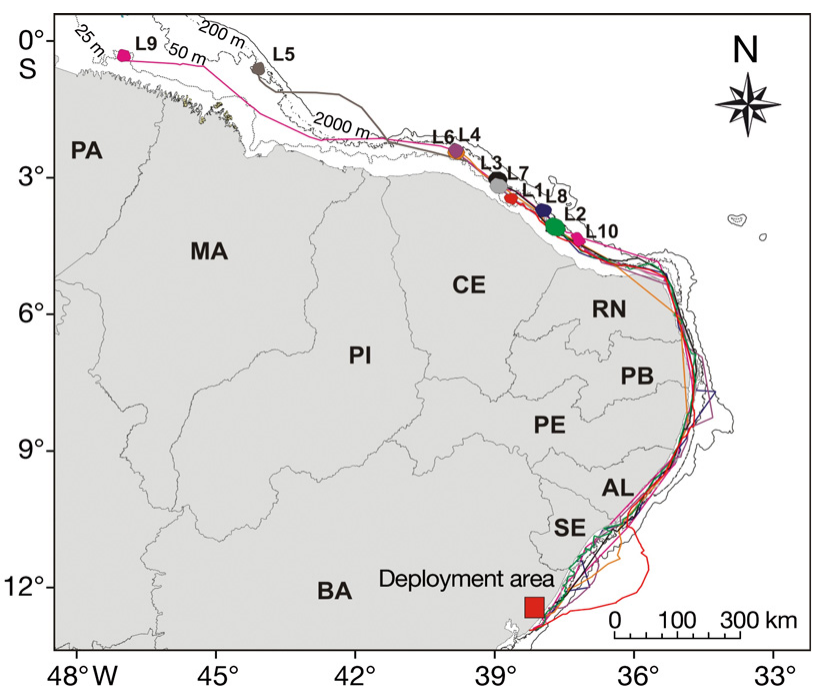

Fig. 5. Caretta caretta. Postnesting movements of 10 loggerheads satellite-tracked from nesting grounds in northern Bahia, Brazil. State abbreviations - PA: Pará; MA: Maranhão; PI: Piauí; CE: Ceará; RN: Rio Grande do Norte; PB: Paraíba; PE: Pernambuco; AL: Alagoas; SE: Sergipe; BA: Bahia

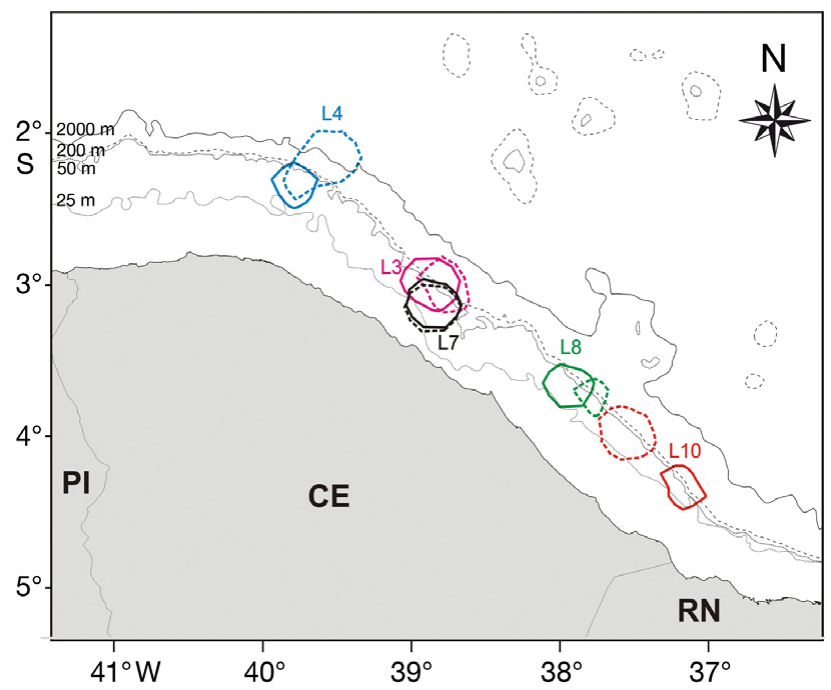

Fig. 6. Caretta caretta. Kernel-estimated home-range utilization $50 \%$ distributions of feeding areas of the 5 tracked loggerheads following their first (solid perimeter) and second (broken perimeter) postnesting migration. State abbreviations - PI: Piauí; CE: Ceará; RN: Rio Grande do Norte 
and south from the nesting area (Lemke et al. 2003), the northern stock turtles traveled to common foraging areas in northern Brazil. Although we observed a distinctive migratory behavior among the 2 stocks, limited tracking duration of individuals from the southern stock (Espírito Santo) and tag recoveries from adult females found stranded in Uruguay from both loggerhead subpopulations (Almeida et al. 2000, Laporta \& Lopez 2003) prevent definitive conclusions on migration patterns.

A seasonal shuttling between foraging and wintering grounds has been observed in several populations from temperate regions as an attempt to avoid lethally cold winter temperatures (Broderick et al. 2007, Hawkes et al. 2007, Zbinden et al. 2008). Following postnesting migrations, females tracked in the present study arrived at foraging grounds and remained within restricted areas until subsequent nesting migrations. Foraging grounds located along the tropical northern coast of Brazil exhibit minimal water temperature variations $\left(27\right.$ to $29^{\circ} \mathrm{C}_{i}$ Freire \& Cavalcanti 1998) during the year and are thus suitable for loggerheads on a yearround basis.

All the loggerheads tracked during the present study remained at their foraging grounds until subsequent reproductive migrations, in a similar manner to other nesting populations (Luschi et al. 2006, Broderick et al. 2007, Zbinden et al. 2008). These results differ from the results on loggerheads nesting at Cape Verde and Japan, where the turtles used both coastal and oceanic foraging areas, and the body size of the individuals correlated markedly with the foraging mode. Turtles foraging neritically were significantly larger than turtles foraging oceanically (Hatase et al. 2002, Hawkes et al. 2006). It seems that the neritic foraging strategy maintained over a long period of time by Brazilian loggerheads leads to the relatively large body size of the population (102.8 $\pm 0.04 \mathrm{~cm} \mathrm{CCL}$, Marcovaldi \& Laurent 1996; $103 \mathrm{~cm}$, Marcovaldi \& Chaloupka 2007).

Little is known about the extent of individual foraging areas (Table 4). Hawkes et al. (2006) reported foraging areas ranging from 112 to $421 \mathrm{~km}^{2}$, using minimum convex polygons. The same procedure was employed by Broderick et al. (2007) to calculate winter and summer home ranges for 3 loggerheads, ranging from 55 (winter) to $331 \mathrm{~km}^{2}$ (summer). Loggerhead foraging areas are typically small in size, on the order of 10s of square kilometers (Schroeder et al. 2003). However, calculated foraging areas for loggerheads from the Bahia coast were larger than those reported previously for other areas (see Table 4). Long-term tracking provided sufficient information to delineate the core foraging area exploited by the turtles during their entire residency (i.e. 2 and 3 nesting years) with more accuracy than was possible in previous studies. In addition, loggerheads are omnivorous and generally forage on benthic organisms such as mollusks, crustaceans and coelenterates in neritic habitats (Hatase et al. 2002); thus, as food resources become depleted, turtles may move among a few preferred foraging sites to utilize a larger foraging area (Schroeder et al. 2003). This may be an explanation for the larger size of foraging areas observed during extended residency. However, the longer tracking period, as well as differences in the methods used in area delimitations, may have led to the larger areas recorded compared to other studies (Table 4). Further studies will address prey availability and habitat characterization of loggerhead foraging grounds to better understand these findings.

Differences in remigration intervals are known to occur from long-term mark-recapture studies. Schroeder et al. (2003) summarize the observed remigration rates obtained from different studies around the world. Our study was the first satellite telemetry study to document such varying intervals. Turtles tagged at the same nesting ground migrated to the same foraging area and traveled back to the nesting site at different intervals ( 2 and 3 nesting years). Differences in observed remigration intervals within sea turtle populations can be assigned to several causes: mortality, variations in the quality of forage and inherent methodological limitations (e.g. flipper tagging) (Limpus \& Nicholls 1988, Schroeder et al. 2003). Further analyses are underway to explore these results in more detail in terms of oceanography and resource availability.

Broderick et al. (2007) tracked 2 loggerhead females during consecutive postnesting migrations to foraging areas in the Mediterranean, where turtles exhibited high levels of fidelity to migratory routes, foraging areas and wintering sites. However, turtles were recaptured at the nesting beach after an interval of 2 to $3 \mathrm{yr}$ and tracked for a second migration; thus, information about the complete residency period at foraging areas and prenesting migration routes was limited. After a second postnesting migration, turtles tracked in the present study returned to the same foraging area, indicating strong philopatry to specific foraging areas, as previously noted by Broderick et al. (2007). Furthermore, our migration data demonstrated fidelity to internesting areas after subsequent nesting seasons, as well as migratory routes from nesting to foraging areas and vice versa.

\section{CONSERVATION IMPLICATIONS}

The northern coast of Brazil has previously been identified as an important foraging ground for green turtles Chelonia mydas (Koch et al. 1969, Meylan et al. 1990, Luschi et al. 1998, Godley et al. 2003b), espe- 
cially the Ceará coast (Lima \& Troëng 2001, NaroMaciel et al. 2007). Our findings demonstrate the importance of these foraging grounds for loggerheads breeding on the coast of Bahia as well. Satellite telemetry was an efficient tool for defining both migratory pathways and the extent of internesting and foraging areas of the tracked turtles.

The 10 tracked loggerheads used distinct areas during internesting periods, related to their tagging site; movements between nesting and foraging areas comprised $>1500 \mathrm{~km}$, along the coast of 10 Brazilian states. This behavior exposes the turtles to different impacts depending on habitat and jurisdiction (e.g. different fisheries and respective time closures, varying licensing criteria in different states) and highlights the need for integrated and complementary actions along the entire delineated migratory corridor. Noteworthy is the fact that the nesting and foraging areas for adult females from the same population are located within a single country. This provides a good starting point for ensuring the long-term protection of this relevant part of the turtle's life cycle, since national policies and conservation measures are already established.

Acknowledgements. We thank CENPES/PETROBRAS (Centro de Pesquisas da PETROBRAS) for supporting the 'Mamíferos e Quelônios Marinhos' project, which included the present study. We thank the field personnel, who worked diligently in patrolling beaches and collecting data. Special thanks go to Soraya Christina Bruno, for valuable help with satellite data management and maps, and to Milagros LópezMendilaharsu for valuable suggestions on this manuscript. Projeto TAMAR is a conservation program of the Brazilian Ministry of the Environment, affiliated with ICMBio and comanaged by Fundação Pró-TAMAR and officially sponsored by Petrobras. The comments of $\mathrm{T}$. Tucker and 3 anonymous reviewers improved the quality of the manuscript.

\section{LITERATURE CITED}

Almeida AP, Baptistotte C, Schineider JA (2000) Loggerhead turtle tagged in Brazil found in Uruguay. Mar Turtle Newsl 87:10

Beyer HL (2004) Hawth's analysis tools for ArcGIS. Available at: www.spatialecology.com/htools

Blumenthal JM, Solomon JL, Bell CD, Austin TJ and others (2006) Satellite tracking highlights the need for international cooperation in marine turtle management. Endang Species Res 2:51-61

Broderick AC, Coyne MS, Fuller WJ, Glen F, Godley BJ (2007) Fidelity and overwintering of sea turtles. Proc R Soc Lond B Biol Sci 274:1533-1538

Bustard HR, Limpus CJ (1971) Loggerhead turtle movements. Br J Herpetol 4:228-230

Coyne MS, Godley BJ (2005) Satellite Tracking and Analysis Tool (STAT): an integrated system for archiving, analyzing and mapping animal tracking data. Mar Ecol Prog Ser 301: $1-7$

Dias GTM, Robrini M, Freire GSF, Figueiredo AG Jr (2004) Cartas de sedimento de fundo. Áreas da oceanografia geológica (sul, central, nordeste e norte)-Programa de avaliacão do potencial sustentável dos recursos vivos na Zona Econômica Exclusiva. REVIZEE. CD-ROM de cartas sedimentológicas. Available at: www.mma.gov.br/port/ sqa/projeto/revizee

Dodd CK, Byles R (2003) Post-nesting movements and behavior of loggerhead sea turtles (Caretta caretta) departing from East-Central Florida nesting beaches. Chelonian Conserv Biol 4:530-536

Freire GSS, Cavalcanti VMM (1998) A cobertura sedimentar quaternária da plataforma continental do estado do Ceará. DNPM/LGMA-UFC, Fortaleza

Girard C, Tucker AD, Calmettes B (2009) Post-nesting migrations of loggerhead sea turtles in the Gulf of Mexico: dispersal in highly dynamic conditions. Mar Biol 156: 1827-1839

Godley BJ, Broderick AC, Glen F, Hays GC (2003a) Post-nesting movements and submergence patterns of loggerhead marine turtles in the Mediterranean assessed by satellite tracking. J Exp Mar Biol Ecol 287:119-134

Godley BJ, Lima EHSM, Åkesson S, Broderick AC and others (2003b) Movement patterns of green turtles in Brazilian coastal waters described by satellite tracking and flipper tagging. Mar Ecol Prog Ser 253:279-288

Godley BJ, Blumenthal JM, Broderick AC, Coyne MS, Godfrey MH, Hawkes LA, Witt MJ (2008) Satellite tracking of sea turtles: Where have we been and where do we go next? Endang Species Res 4:3-22

Griffin D (2002) GIS analysis of inter-nesting habitat, migratory corridors, and resident foraging areas of the loggerhead sea turtle (Caretta caretta) along the southeast coast. Masters thesis, College of Charleston, Charleston, SC

Hatase H, Takai N, Matsuzawa Y, Sakamoto W and others (2002) Size-related differences in feeding habitat use of adult female loggerhead turtles Caretta caretta around Japan determined by stable isotope analyses and satellite telemetry. Mar Ecol Prog Ser 233:273-281

> Hawkes LA, Broderick AC, Coyne MS, Godfrey MH and others (2006) Phenotypically linked dichotomy in sea turtle foraging requires multiple conservation approaches. Curr Biol 16:990-995

Hawkes LA, Broderick AC, Coyne MS, Godfrey MH, Godley BJ (2007) Only some like it hot - quantifying the environmental niche of the loggerhead sea turtle. Divers Distrib 13:447-457

Hays GC (2008) Sea turtles: a review of some key recent discoveries and remaining questions. J Exp Mar Biol Ecol 356:1-7

Hays GC, Åkesson S, Godley BJ, Luschi P, Santidrian P (2001) The implications of location accuracy for the interpretation of satellite tracking data. Anim Behav 61:1035-1040

Hopkins SR, Murphy TM (1981) Reproductive ecology of Caretta caretta in South Carolina. Study Completion Report, South Carolina Wildlife and Marine Resources Department, p 1-97

Hopkins-Murphy S, Owens DW, Murphy TM (2003) Ecology of benthic immature loggerhead turtles (Caretta caretta) on foraging grounds and internesting habitat use by adult females-Atlantic. In: Bolten AB, Witherington BE (eds) Loggerhead sea turtles. Smithsonian Institution Press, Washington, DC, p 319

Hughes GR (1982) Nesting cycles in sea turtles, typical or atypical? In: Bjorndal KA (ed) Biology and conservation of sea turtles. Smithsonian Institution Press, Washington, DC, p 81-89

Koch AL, Carr A, Ehrenfeld DW (1969) The problem of opensea navigation: the migration of the green turtle to Ascension Island. J Theor Biol 22:163-179 
Laporta M, Lopez G (2003) Loggerhead sea turtle tagged in Brazil caught by a trawler in waters of the common Argentinian-Uruguayan Fishing Area. Mar Turtle Newsl 102:14

Lemke D, Frazier JG, Thomé JCA, Almeida AP, Scalfoni J (2003) Satellite telemetry of loggerheads in Brazil. In: Pilcher NJ (compiler) Proc 23rd Annu Symp Sea Turtle Biol Conserv, 17-21 March 2003, Kuala Lumpur NOAA Tech Memo 536:230-233

Lima EHSM, Troëng S (2001) Link between green turtles foraging in Brazil and nesting in Costa Rica? Mar Turtle Newsl 94:9

Limpus CJ, Limpus DJ (2001) The loggerhead turtle, Caretta caretta, in Queensland: breeding migrations and fidelity to a warm temperate feeding area. Chelonian Conserv Biol 4:142-153

Limpus CJ, Limpus DJ (2003) Biology of the loggerhead turtle in western South Pacific Ocean foraging areas. In: Bolten $\mathrm{AB}$, Witherington $\mathrm{BE}$ (eds) Loggerhead sea turtles. Smithsonian Institution Press, Washington, DC, p 93-113

Limpus CJ, Nicholls N (1988) The Southern Oscillation regulates the annual numbers of green turtles (Chelonia mydas) breeding around northern Australia. Aust Wildl Res 15:157-161

Limpus CJ, Reed PC (1985) The loggerhead turtle, Caretta caretta, in Queensland: observations on internesting behaviour. Aust Wildl Res 12:535-540

Limpus CJ, Miller JD, Parmenter J, Reimer D, Mc Lachlan N, Webb R (1992) Migration of green (Chelonia mydas) and loggerhead (Caretta caretta) turtles to and from eastern Australia rookeries. Wildl Res 19:347-358

Luschi P, Hays GC, Del Seppia C, Marsh R, Papi F (1998) The navigational feats of green sea turtles migrating from Ascension Island investigated by satellite telemetry. Proc Biol Sci 265:2279-2284

Luschi P, Lutjeharm JRE, Lambardi R, Mencacci R, Hughes GR, Hays GC (2006) A review of migratory behaviour of sea turtles off southeastern Africa. S Afr J Sci 102:51-58

> Mansfield K, Saba VS, Keinath JA, Musick JA (2009) Satellite tracking reveals a dichotomy in migration strategies among juvenile loggerhead turtles in the Northwest Atlantic. Mar Biol 156:2555-2570

Marcovaldi M, Chaloupka M (2007) Conservation status of the loggerhead sea turtle in Brazil: an encouraging outlook. Endang Species Res 3:133-143

Marcovaldi MA, Laurent A (1996) A six-season study of marine turtle nesting at Praia do Forte, Bahia, Brazil, with implications for conservation and management. Chelonian Conserv Biol 2:55-59

Marcovaldi MA, Marcovaldi GG (1999) Marine turtles of Brazil: the history and structure of Projeto TAMARIBAMA. Biol Conserv 91:35-41

Marcovaldi MA, Silva ACCD, Gallo BMG, Baptistotte C and others (2000) Recaptures of tagged turtles from nesting and feeding grounds protected by Projeto TAMARIBAMA, Brasil. In: Kalb HJ, Wibbels T (compilers) Proc 19th Annu Symp Sea Turtle Biol Conser, 2-6 March 1999, South Padre Island, TX, USA. NOAA Tech Memo 443: 164-166

Meylan A (1982) Sea turtle migration-evidence from tag returns. In: Bjorndal KA (ed) Biology and conservation of sea turtles. Smithsonian Institution Press, Washington, DC, p 91-100

Editorial responsibility: Brendan Godley,

University of Exeter, Cornwall Campus, UK
Meylan AB, Bowen BW, Avise JC (1990) A genetic test of the natal homing versus social facilitation models for green turtle migration. Science 248:724-727

> Naro-Maciel E, Becker JH, Lima HSM, Marcovaldi MA, Desalle R (2007) Testing dispersal hypotheses in foraging green sea turtles (Chelonia mydas) of Brazil. J Hered 98: 29-39

Papi F, Luschi P, Crosio E, Hughes GR (1997) Satellite tracking experiments on the navigational ability and migratory behaviour of the loggerhead turtle Caretta caretta. Mar Biol 129:215-220

> Plotkin PT, Spotila JR (2002) Post-nesting migrations of loggerhead turtles Caretta caretta from Georgia, USA: conservation implications for a genetically distinct subpopulation. Oryx 36:396-399

> Polovina JJ, Balazs GH, Howell EA, Parker DM, Seki MP, Dutton PH (2004) Forage and migration habitat of loggerhead (Caretta caretta) and olive ridley (Lepidochelys olivacea) sea turtles in the central North Pacific Ocean. Fish Oceanogr 13:36-51

Reis EC, Soares LS, Vargas SM, Santos FR and others (2009) Genetic composition, population structure and phylogeography of the loggerhead sea turtle: colonization hypothesis for the Brazilian rookeries. Conserv Gen 11:1467-1477

Sakamoto W, Naito Y, Uchida I, Kureha K (1990) Circadian rhythm on diving motion of the loggerhead turtle Caretta caretta during inter-nesting and its fluctuations induced by oceanic environmental events. Bull Jpn Soc Sci Fish 56:263-272

Schroeder BA, Foley AM, Bagley DA (2003) Nesting patterns, reproductive migrations, and adult foraging areas of loggerhead turtles. In: Bolten AB, Witheringto BE (eds) Loggerhead sea turtles. Smithsonian Books, Washington, DC, p 114-124

Silverman BW (1986) Density estimation for statistics and data analysis. Chapman \& Hall, London

Stoneburner DL (1982) Satellite telemetry of loggerhead sea turtle movement in the Georgia Bight. Copeia 1982: $400-408$

Timko RE, Kolz L (1982) Satellite sea turtle tracking. Mar Fish Rev 44:19-24

Troeng S, Evans DR, Harrison E, Lagueux CJ (2005) Migration of green turtles Chelonia mydas from Tortuguero, Costa Rica. Mar Biol 148:435-447

Tucker AD (2009) Eight nests recorded for a loggerhead in one season. Mar Turtle Newsl 124:16-17

Tucker AD (2010) Nest site fidelity and clutch frequency of loggerhead turtles are better elucidated by satellite telemetry than by nocturnal tagging efforts: implications for stock estimation. J Exp Mar Biol Ecol 383:48-55

Tucker AD, Fitzsimmons NN, Limpus CJ (1996) Conservation implications of internesting habitat use by loggerhead turtles, Caretta caretta, in Woongarra Marine Park, Queensland, Australia. Pac Conserv Biol 2:157-166

Zbinden JA, Aebischera A, Margaritoulis D, Arlettaza R (2007) Insights into the management of sea turtle internesting area through satellite telemetry. Biol Conserv 137: $157-162$

> Zbinden JA, Aebischer A, Margaritoulis D, Arlettaz R (2008) Important areas at sea for adult loggerhead sea turtles in the Mediterranean Sea: satellite tracking corroborates findings from potentially biased sources. Mar Biol 153: 899-906

Submitted: January 6, 2010; Accepted: August 11, 2010

Proofs received from author(s): October 18, 2010 